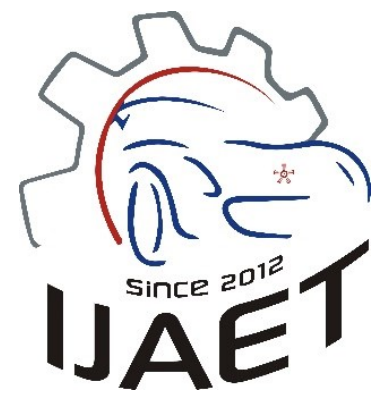

e-ISSN: 2146 - 9067

International Journal of Automotive

Engineering and Technologies

journal homepage: http://ijaet.academicpaper.org

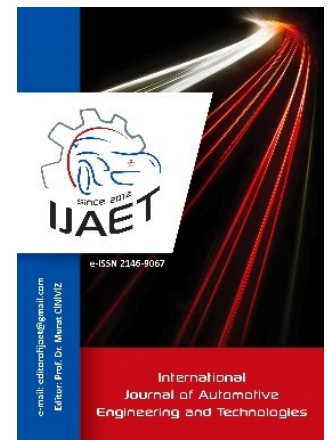

Original Research Article

\title{
Investigation of the Effects of Linseed Oil Biodiesel and Diesel Fuel Blends on Engine Performance and Exhaust Emissions
}

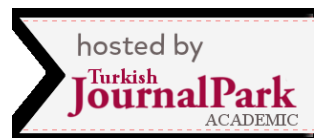

\author{
Seda Şahin ${ }^{1 *}$, Hüseyin Öğ̈̈t ${ }^{2}$ \\ 1,* Selçuk University, Faculty of Agriculture, Agricultural Machinery and Technology Engineering, Konya, Turkey \\ ${ }^{2}$ Kyrgyzstan-Turkey Manas University - Selcuk University
}

\author{
ARTICLE INFO \\ * Corresponding author \\ sedabacak@selcuk.edu.tr \\ Received: November 02, \\ 2018 \\ Accepted: December 11, \\ 2018
}

Published by Editorial Board Members of IJAET

(C) This article is distributed by Turk Journal Park System under the CC 4.0 terms and conditions.

\begin{abstract}
In this study, linseed oil was obtained with the aid of screw presses and linseed oil biodiesel (B100) (linseed oil methyl ester) production was performed by transesterification method. Linseed biodiesel was blended with regular diesel fuel at different ratios as B2 (98\% diesel $+2 \%$ biodiesel), B5 (95\% diesel + $5 \%$ biodiesel), B20 (80\% diesel $+20 \%$ biodiesel), B50 (50\% diesel $+50 \%$ biodiesel). Fuel properties tests were performed on all fuels. Results revealed that engine performance values of linseed biodiesel and fuel blends were similar with the standard diesel fuel. With regard to maximum torque, while the highest value was obtained as about $59.6 \mathrm{Nm}$ at $1000 \mathrm{rpm}$ with diesel fuel, the value was observed as about $53.8 \mathrm{Nm}$ at $12001 / \mathrm{min}$ with B100 fuels. The highest maximum power output was recorded as approximately $10.96 \mathrm{~kW}$ at $2100 \mathrm{rpm}$ with diesel fuel and as approximately $10.23 \mathrm{~kW}$ at $2000 \mathrm{rpm}$ with B100 fuels. With regard to minimum specific fuel consumption, while the lowest value was measured as about $231.36 \mathrm{~g} / \mathrm{kWh}$ at $1000 \mathrm{rpm}$ with diesel fuel, the value was measured as about $296.73 \mathrm{~g} / \mathrm{kWh}$ at $1200 \mathrm{rpm}$ with $\mathrm{B} 100$ fuels. Exhaust emissions are generally improved by the addition of linseed biodiesel to diesel fuel.
\end{abstract}

Keywords: Biodiesel, biodiesel - diesel fuel blends, linseed-flaxseed, linseed oil, transesterification

\section{Introduction}

The number of studies on energy has recently been increasing. Just because of depletion and environmental impacts of fossil fuels, researches on alternative energy sources have gained a great significance and acceleration. There is a significant increase in number of studies on alternative energy sources in Turkey [1].
Fossil fuels have the greatest share in primary energy sources and these sources are distributed throughout the world in an unbalanced fashion. Such a case made some countries advantageous, but made some others dependent on those advantageous ones. Such a dependence solidified even more with the increasing energy demands of dependent countries. Therefore, countries are now in search for appraisal of their own energy sources and they are trying to 
diversify their energy sources to reduce their dependency on foreign countries and to provide supply security [2].

Biofuels are produced from new or used vegetable oils or animal fats through chemical methods. These environment-friendly renewable liquid fuels are also called as biodiesel [3]. Biodiesel is produced from raw or refined oils of sunflower, rapeseed, soybean, safflower, maize, linseed or the other oil-seeds or from animal fats through the reaction of an alcohol (methanol or ethanol) with the aid of a catalyzer (acidic, basic or enzymatic). It is used as a renewable fuel.

Biodiesel is quite similar with petroleum diesel fuels in physical and chemical aspects. Biodiesel can either be used alone in diesel engines or blended with petroleum diesel fuels. Pure biodiesel and diesel-biodiesel blends can be used in diesel engines without any modifications or with slight modifications on engine. While pure biodiesel is entitled as B100, $20 \%$ biodiesel $-80 \%$ diesel blend is entitled as B20 [4].

In this study, it was aimed to compare the results of fuel characteristics, engine performance and exhaust emissions of linseed biodiesel mixed with diesel fuel in different ratios.

\subsection{Improvement of fuel characteristics of vegetable oils}

The studies about the improvement of fuel characteristics of vegetable oils initially focused on reducing oil viscosities. The different methods (heat and chemical) are used to reduce viscosity of vegetable oils [4]. The chemical methods used to reduce viscosity include dilution, micro emulsion formation, pyrolysis and transesterification. Of these methods, transesterification is the most common one. Transesterification, also called as alkalosis, is a process applied to reduce viscosity of triglycerides. The method includes esterification of vegetable oils with a monohydric alcohol (methanol, ethanol) a catalyzer (acidic, basic catalyzer and enzymes) through formation of fatty acid esters and glycerin as the primary products [5]. Although methanol, ethanol, butanol and amyl alcohols are able to be used in transesterification process, methyl alcohol is commonly used because of low costs, chemical and physical advantages [6].

\subsection{Linseed}

Linseed (Linum usitatissimum) is an annual crop with 30-100 cm plant height and blue flowers. The Latin name of the plant means "very beneficial plant". It has been cultivated since the ancient Egyptians and used for various purposes. Seeds are 4-6 cm long, oval in shape, bright, reddish colored, unscented, tasty and oily [7].

Linseed seeds contain about $30-40 \%$ fixed oils including linoleic, linolenic and oleic acids, viscous plant juice, protein and glycoside called promarin. The linseed oil obtained from plant seeds is used in dyeing, linoleum production and nutrient industry. The pulp after oil extraction from the seeds is used as animal feed. The fibers are used in linen yarn production and textile industry [8].

Linseed contain about 6,5-10\% moisture, 20$24 \%$ protein, $40-45 \%$ oil, $15-29 \%$ crude cellulose, $4,8-9 \%$ carbohydrate and $2,4-4 \%$ crude ash. Specific weight of linseed is between $0,924-0,926 \mathrm{~g} / \mathrm{cm}^{3}$.

Fatty acids ratio of linseed was indicated as between $30-40 \%$. Fixed oils are largely composed of unsaturated fatty acids; linoleic acid contents are between 36-50\%, linolenic acid contents are between $10-25 \%$ and oleic acid contents are between $13-30 \%$. Saturated fatty acid contents are between $5-11 \%$ and meristic acid palmitic acid and stearic acid are the major components $[9,10,11]$.

Table 1.1. Properties of linseed oil [12].

\begin{tabular}{lc}
\hline & Linseed oil \\
\hline Refraction index & $1,474-1,479$ \\
Melting point & 0 \\
Saponification value & $189-194$ \\
Iodine value & $175-185$ \\
Acid value & $1-3$ \\
Non-saponified substance $(\%)$ & $0,5-1,5$ \\
\hline
\end{tabular}

P. Karthikeyan et al., (2017), conducted an experimental study on a single-cylinder, fourstroke direct injection diesel engine with a output of $5.2 \mathrm{~kW}$ at $1500 \mathrm{rpm}$ at various injection times 20,23, 26 degrees BTDC for observe the performance and emission characteristics of direct injection diesel engine by using methyl esters of linseed oil and mixtures. Linseed biodiesel has better properties than petroleum diesel fuel. The results showed an increase in BTHE and a reduction in SFC compared to diesel. NOx was less in both 
biodiesel mixtures. The $\mathrm{CO}$ and $\mathrm{HC}$ emissions were slightly higher. They found that when injection increased, performance and emissions increased [13].

L. Narsinga Rao et al. (2017) evaluated the various performance and emission parameters like brake power (BP), brake specific fuel consumption(BSFC), Brake thermal efficiency (BTE), $\mathrm{CO}$ emissions, $\mathrm{CO}_{2}$ emissions, $\mathrm{HC}$ emissions, NOx emissions and smoke were evaluated at different loads in a 4 stroke, single cylinder Diesel engine. These performance and emission parameters of diesel fuel were compared with B25, B50, B75 and B100. BTE for Linseed oil is lower by $34.60 \%$ compared to diesel. BSFC is higher by $54.76 \%$ compared to diesel at rated load. CO emission for Linseed oil $96 \%$ compared to diesel at rated load. The performance and emissions for $25 \%$ blend of Linseed oil is better than that of all other blends and is alternate fuel to diesel in C.I. Engine [14]. M. M. Tunio et al., (2018), produced linseed biodiesel by transesterification process and then mixed with blends of $10 \%$ (LB10), $20 \%$ (LB20) and $30 \%$ (LB30) volume of petro-diesel fuel (D100). The fuel properties of the produced biodiesel were found to comply with the ASTM standards. The specific fuel consumption (SFC) of the LB10 mixture was less than that of LB20 and LB30. The SFC of the D100 is slightly less than all the mixes. Brake Thermal Efficiency of LB30 is greater than D100 at the maximum load. It was found that the rate of heat distribution in all linseed biodiesel mixtures was less than in D100. Carbon monoxide, carbon dioxide and NOx emissions of linseed biodiesel mixtures are lower than D100. It is concluded that LB10 may be the most suitable alternative fuel for diesel engines and can be blended with petro diesel without engine modifications [15].

\section{Material and Method}

\subsection{Test fuels}

The study was carried out in six stages as follows.

- Obtaining linseed oil from linseed for methyl ester to be used as alternative fuel in diesel engine,

- Determination of physical and chemical properties of obtained linseed oil,

- Production of linseed oil methyl ester to be used as alternative fuel in diesel engine,
- Preparation of B2, B5, B20, B50 fuel mixtures, - Determination of fuel properties of B2, B5, B20, B50, B100 and diesel fuel.

- Preparation of the engine tester and performed engine tests according to TS 1231 standard.

For biodiesel production from linseed oil, initially a screw press was used to obtain linseed oil.

Linseed oil (30 liters) was placed in an oil tank in pilot plant. From there, the oil was pumped into oil reactor. The reactor was heated until $55^{\circ} \mathrm{C}$. The temperature was kept constant throughout the reaction with a thermostat controller. A mixer was used for homogeneous oil temperature distribution in every place of the reactor.

Linseed oil was then supplemented with 6 liters methanol corresponding to $20 \%$ of oil volume and 105 gram $\mathrm{NaOH}$ catalyzer (as to have $3.5 \mathrm{~g}$ catalyzer per liter oil). The reaction was implemented in two phases. Methanol (6 liters) and $\mathrm{NaOH}$ catalyzer (105 gram) were dissolved in methoxide tank and send to reactor while mixing the oil. The mixture was mixed for 60 minutes. The mixture was rested for 2 hours and 2.5 liters glycerol was obtained. The raw biodiesel in reactor was sent to settling/washing tank, waited there for 15 hours to settle glycerol and to cool biodiesel. Following 15 hours, 2.5 liters more glycerol was obtained.

Biodiesel was subjected to washing with distilled water through misting. The objective of washing is to remove alcohol left in biodiesel without reacting, residual fatty acids, $\mathrm{Na}+, \mathrm{K}+$ ions, catalyzer substances and potential residual glycerol. During washing process, biodiesel temperature was $50^{\circ} \mathrm{C}$ and distilled water temperature was also $50^{\circ} \mathrm{C}$ and a total of 10 liters distilled water were used. Following the washing process, it was waited for 12 hours to settle the water. Settled water was then sent to waste water tank.

Heater of settling/washing tank was turned on and biodiesel was heated until the boiling point of water $\left(100^{\circ} \mathrm{C}\right)$. Water vapor was then discharged from the settling/washing tank through a vacuum pump. Biodiesel was dried at $100^{\circ} \mathrm{C}$ for 2 hours. Linseed biodiesel was filtered through fuel filter connected to biodiesel tank. In this way, biodiesel was produced from linseed oil. Resultant biodiesel was blended with diesel fuel to get B2, B5, B20 and B50 
blends.

Linseed oil, methyl ester of linseed oil (B100), blends of B50, B20, B5, B2 and diesel fuel were analyzed at Biodiesel Laboratory of Agricultural Faculty at Selçuk University. Analysis results are provided in Table 2.1. Following the transesterification of linseed oil methyl esters, fuel characteristics of B2, B5,
B20, B50 and B100 blends were compared in accordance with TS EN 14214 for B100 and with TS 3082 EN 590 for blends and color characteristics were compared in accordance with ASTM standards. It was observed that density, viscosity, flash point, water content, copper strip corrosion and color analyses were all within limit values.

\begin{tabular}{|c|c|c|c|c|c|c|c|}
\hline & Diesel & $\mathrm{B} 100$ & $\mathrm{~B} 50$ & $\mathrm{~B} 20$ & B5 & $\mathrm{B} 2$ & Crude Linseed Oil \\
\hline Density $15^{\circ} \mathrm{C}\left(\mathrm{g} / \mathrm{cm}^{3}\right)$ & 0.826 & 0.897 & 0.861 & 0.840 & 0.839 & 0.831 & 0.933 \\
\hline Kinematic Viscosity $40^{\circ} \mathrm{C}\left(\mathrm{mm}^{2} / \mathrm{s}\right)$ & 2.822 & 4.274 & 3.3 & 3.024 & 2.877 & 2.851 & 26.922 \\
\hline Flash Point $\left({ }^{\circ} \mathrm{C}\right)$ & 60 & 148 & 78 & 72 & 67 & 66 & $>200$ \\
\hline Water Content $(\mathrm{mg} / \mathrm{kg})$ & 8.793 & 489.42 & 238.14 & 85.40 & 40.68 & 31.13 & 522.37 \\
\hline $\mathrm{pH}$ & 6 & 5.5 & 5.6 & 5.7 & 5.8 & 5.9 & 6.5 \\
\hline Color test (ASTM) & $<0.5$ & 1.1 & 0.8 & 0.6 & 0.5 & 0.5 & 2.2 \\
\hline Calorie Value $(\mathrm{MJ} / \mathrm{kg})$ & 47.5 & 39.56 & 42.27 & 46.66 & 47.26 & 47.39 & 41.018 \\
\hline Cloud Point $\left({ }^{\circ} \mathrm{C}\right)$ & -12 & -4 & -6 & -8 & -10 & -11 & - \\
\hline Pour Point $\left({ }^{\circ} \mathrm{C}\right)$ & -28 & -12 & -16 & -19 & -22 & -24 & - \\
\hline Cold Filter Plugging Point $\left({ }^{\circ} \mathrm{C}\right)$ & -20 & -2 & -9 & -12 & -13 & -13 & - \\
\hline Copper Strip Corrosion & 1a & $1 \mathrm{a}$ & $1 \mathrm{a}$ & $1 \mathrm{a}$ & $1 \mathrm{a}$ & $1 \mathrm{a}$ & $1 \mathrm{a}$ \\
\hline
\end{tabular}

\subsection{Test apparatus and experimental setup}

Diesel engine and hydraulic dynamometer given to specifications in Table 2.2 was used in the tests. Mobydic -5000 model gas analyzer given to technical properties in Table 2.3. was used for exhaust gas measurements.
The experiments were performed in experimental setup shown schematically in Figure 2.1. The tests for all test fuels were performed with $100 \mathrm{rpm}$ intervals between $1000-2200 \mathrm{rpm}$ by changing engine load when the engine was in full gas position.

Table 2.2. The specifications of test engine and hydraulic dynamometer

\begin{tabular}{lll}
\hline Super Star Engine & Units & Value \\
\hline Working principle & --- & 4 stroke, direct injection \\
Cylinder Bore & $\mathrm{mm}$ & 108 \\
Stroke & $\mathrm{mm}$ & 100 \\
Cylinder Number & --- & 1 \\
Cylinder Volume & 1 & 0.92 \\
Compression Ratio & --- & $17: 1$ \\
Maximum Power & $\mathrm{HP}$ & $15\left(2100 \mathrm{~min}^{-1}\right)$ \\
Maximum Torque & $\mathrm{Nm}$ & $60\left(1100 \mathrm{~min}^{-1}\right)$ \\
Maximum Speed & $\mathrm{min}^{-1}$ & 2600 \\
Cooling System & --- & Water Cooling \\
Injection Advance & $\mathrm{kg} / \mathrm{cm}^{2}$ & 175 \\
Injection Advance & $\mathrm{degree}$ & $28-35^{0}($ Crank Shaft angle $)$ \\
\hline \multicolumn{2}{c}{ Technical specifications of hydraulic dynamometer } \\
\hline Maximum torque & $\mathrm{Nm}$ & 1700 \\
Maximum speed & $\mathrm{Rpm}$ & 7500 \\
\hline
\end{tabular}

Table 2.3. The specifications of exhaust gas analyzer

\begin{tabular}{ccc}
\hline Measuring Range & Unit & Value \\
\hline $\mathrm{CO}$ & $\%$ Vol & $0-10$ \\
$\mathrm{CO}_{2}$ & $\%$ Vol & $0-20$ \\
$\mathrm{HC}$ & ppm Vol & $0-20000$ \\
$\mathrm{O}_{2}$ & $\%$ Vol & $0-21$ \\
$\mathrm{NO}_{\mathrm{x}}$ & $\mathrm{ppm}$ & $0-500$ \\
$\mathrm{SO}_{2}$ & $\mathrm{ppm}$ & $0-500$ \\
Lambda $(\lambda)$ & --- & $0-5$ \\
\hline
\end{tabular}




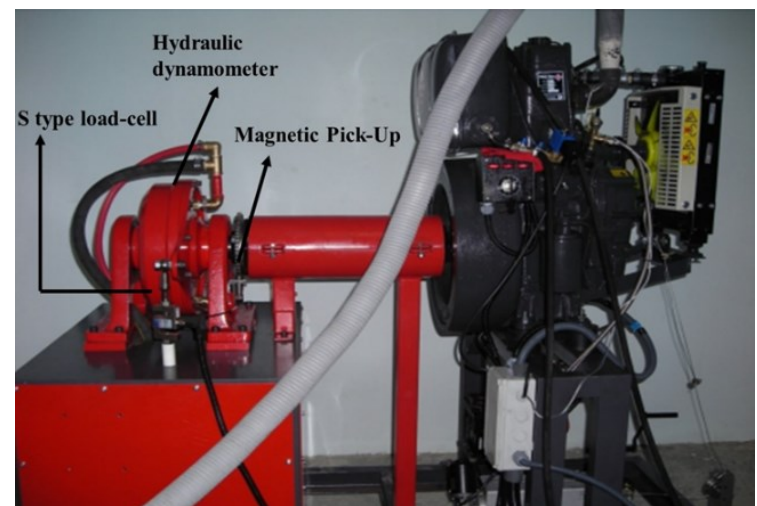

Figure 2.1 Engine and hydraulic dynamometer used in experiments

\section{Results and Discussion}

\subsection{Comparison of engine torque values}

Effective torque values received from flywheel with the use of different fuel blends were compared in Figure 3.1. Among the fuels, the greatest torque value was obtained from 1000 rpm engine speed in B2 fuels, from $1100 \mathrm{rpm}$ in B5 fuels, $1400 \mathrm{rpm}$ in B20 fuels and $1200 \mathrm{rpm}$ in B50 and B100 fuels. When the pure biodiesel was compared with biodiesel blends, it was observed that torque value obtained from fuel blends decreased as compared to diesel fuel. Such a decrease average was about $2.28 \%$ in B2 fuels, $5.21 \%$ in B5 fuels, $7.00 \%$ in B20 fuels, $8.00 \%$ in B50 fuels and $9.51 \%$ in B100 fuels. As it can be seen from the Figure 3.1, the decrease ratio in engine torque values increased with increasing biodiesel ratios in fuel blends.

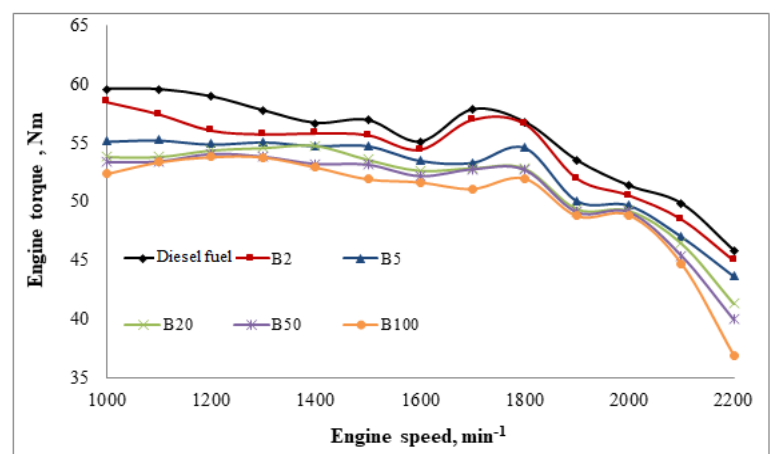

Figure 3.1. Engine torque value for diesel, B2, B5, B20, B50 and B100 fuels

The major important causes of decrease at engine torque with using biodiesel can explain with its lower calorific value compared to diesel fuel. Engine torque decreased by rising of biodiesel rate in blends owing to a decrease in heat energy in cylinder at burn-end due to decline of lower heating value. Furthermore, high density and viscosity of biodiesel caused bad spray characteristics such as higher droplet diameter, less amount fuel injected etc. Therefore, combustion worsen, and torque is decreased $[16,17]$.

\subsection{Comparison of effective power changes}

The effects of biodiesel on engine power calculated based on torque values are presented in Figure 3.2. According to test values of fuel blends, the greatest power value was achieved at $2100 \mathrm{rpm}$ in diesel fuel, at $1800 \mathrm{rpm}$ in B2 fuels and at $2000 \mathrm{rpm}$ in B5, B20, B50 and B100 fuels. In general, engine power values decreased with the use of biodiesel. As compared to diesel fuel, such a decrease was measured as $2.21 \%$ in B2 fuels, $0.3 \%$ in B5 fuels, $1.54 \%$ in B20 fuels, $1.00 \%$ in B50 fuels and $1.21 \%$ in B100 fuels.

The decrease ratios in engine power increased with increasing engine speeds and biodiesel ratios.

The major cause of decrease in effective power with rise of biodiesel ratio within blends is their lower calorific value. Besides, biodiesel's bad flow properties effected combustion negatively $[18,19]$.

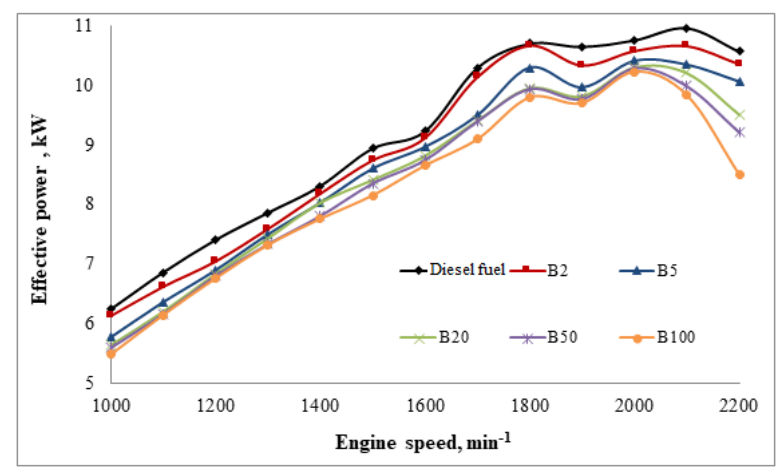

Figure 3.2. Effective power values for diesel, B2, B5, B20, B50 and B100 fuels

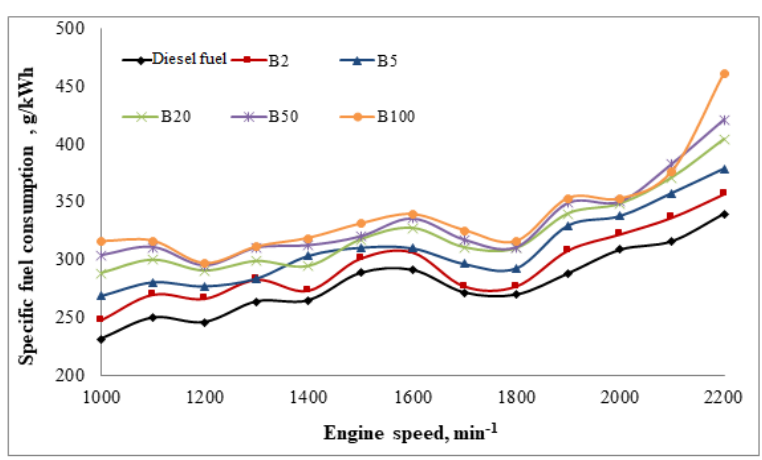

Figure 3.3. Specific fuel consumption values for diesel, B2, B5, B20, B50 and B100 fuels

\subsection{Comparison of specific fuel consumption values}

The amount of fuel consumed per unit power output is expressed as specific fuel 
consumption. The effects of biodiesel on specific fuel consumptions are presented in Figure 3.3. According to tests carried on all fuels, the lowest specific fuel consumption was obtained from $1000 \mathrm{rpm}$ in diesel, B2, B5 and B20 fuels and from $1200 \mathrm{rpm}$ in B50 and B100 fuels. In general, specific fuel consumptions increased with the use of biodiesel. As compared to diesel fuel, such an increase was measured as $5.5 \%$ in B2 fuels, $11.00 \%$ in B5 fuels, $16.00 \%$ in B20 fuels, $19.1 \%$ in B50 fuels and $21.63 \%$ in B100 fuels. As reported by P. Karthikeyan et al (2017) and L. Narsinga Rao et al. (2017) increasing specific fuel consumption values were observed with increasing biodiesel ratios in blends.

Biodiesel increased specific fuel consumption due to bad combustion performance quality as well as its lower calorific value [20,21].

\subsection{Comparison of exhaust gas temperature values}

The effects of biodiesel on comparison of exhaust gas temperature are presented in Figure 3.4. According to tests carried on all fuels, the highest comparison of exhaust gas temperature was obtained from $1900 \mathrm{rpm}$ in for diesel fuel and all blends. In general, comparison of exhaust gas temperature increased with the use of biodiesel. As compared to diesel fuel, such an increase was measured as $4.3 \%$ in B2 fuels, $6.29 \%$ in B5 fuels, $10.26 \%$ in B20 fuels, $13.85 \%$ in B50 fuels and $16.65 \%$ in B100 fuels. The oxygen in biodiesel is caused almost full combustion. Therefore, combustion efficiency is improved owing to oxygen. Exhaust gas temperature increased due to shorten of combustion duration and the better combustion $[22,23]$.

\subsection{Comparison of $\mathrm{CO}$ emission values}

The effects of biodiesel on comparison of $\mathrm{CO}$ emission values are presented in Figure 3.5. In general, comparison of $\mathrm{CO}$ emission values decreased with the use of biodiesel. As compared to diesel fuel, such a decrease was measured as $3.9 \%$ in B2 fuels, $6.86 \%$ in B5 fuels, $18.33 \%$ in B20 fuels, $30.65 \%$ in B50 fuels and $58.34 \%$ in B100 fuels. Decreasing comparison of $\mathrm{CO}$ emission values were observed with increasing biodiesel ratios in blends. Similar results were also reported by P.
Karthikeyan et al. (2017) and M. M. Tunio et al (2018). Biodiesel has lower stoichiometric air/fuel ratio. Therefore, it needs lower oxygen for burning. The oxygen in biodiesel caused that $\mathrm{C}$ atoms found enough $\mathrm{O}$ atoms and they formed $\mathrm{CO}_{2}$. Hence, $\mathrm{CO}$ emission values of biodiesel and its blends decreased due to oxygen contents compare to diesel fuel $[24,25]$.

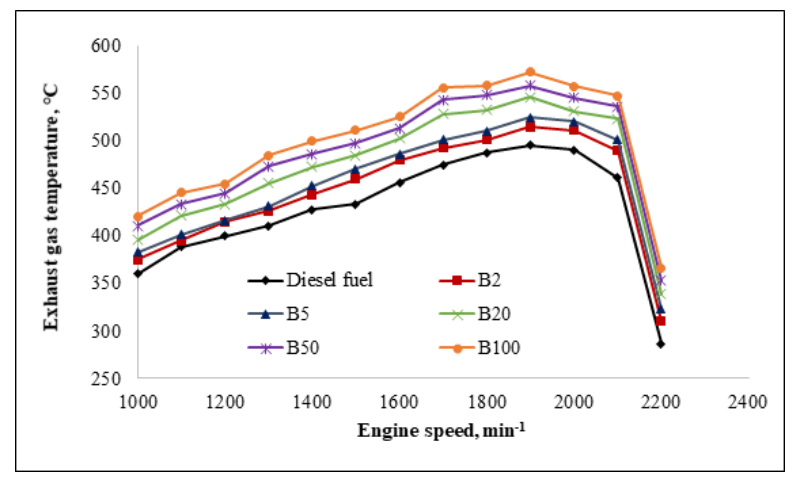

Figure 3.4. Exhaust gas temperature values for diesel, B2, B5, B20, B50 and B100 fuels

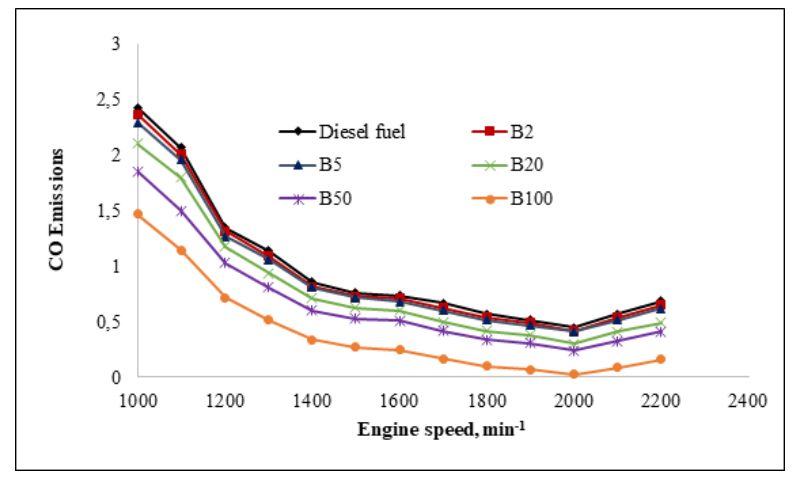

Figure 3.5. Comparison of $\mathrm{CO}$ emission values for diesel, B2, B5, B20, B50 and B100 fuels

\subsection{Comparison of $\mathrm{CO}_{2}$ emission values}

The effects of biodiesel on comparison of $\mathrm{CO}_{2}$ emission values are presented in Figure 3.5. In general, comparison of $\mathrm{CO}_{2}$ emission values increased with the use of biodiesel. Similar results were obtained in the study of $\mathrm{M}$. M. Tunio et al (2018). As compared to diesel fuel, such an increase was measured as $7.50 \%$ in B2 fuels, $23.30 \%$ in B5 fuels, $44.71 \%$ in B20 fuels, $53.89 \%$ in B50 fuels and $68.04 \%$ in B100 fuels. Increase of $\mathrm{CO}_{2}$ emission values by use biodiesel can explain that its $\mathrm{C}$ atoms amount higher than that diesel fuel $[26,27]$.

\subsection{Comparison of $\mathrm{HC}$ emission values}

The effects of biodiesel on comparison of HC emission values are presented in Figure 3.7. In general, comparison of $\mathrm{HC}$ emission values decreased with the use of biodiesel. Karthikeyan P. et al. (2017), reported that due to the less 
oxygen content in the biodiesel mixes, slow burning occurred and thus they released less hydrocarbons. As compared to diesel fuel, such a decrease was measured as $6.55 \%$ in B2 fuels, $16.99 \%$ in B5 fuels, $25.99 \%$ in B20 fuels, $41.55 \%$ in B50 fuels and $58.11 \%$ in B100 fuels. Increase of exhaust gas temperature due to biodiesel's oxygen contents caused decrease of $\mathrm{HC}$ emission. Besides, $\mathrm{HC}$ emissions decreased due to earlier combustion of biodiesel $[28,29]$.

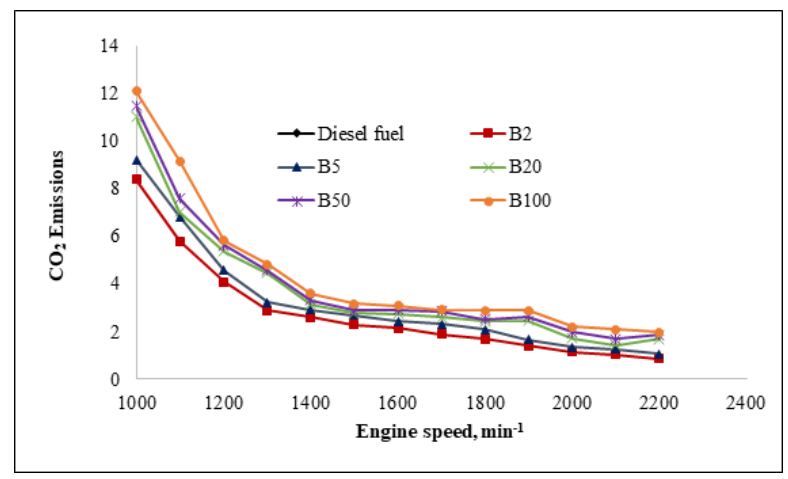

Figure 3.6. Comparison of $\mathrm{CO}_{2}$ emission values for diesel, B2, B5, B20, B50 and B100 fuels

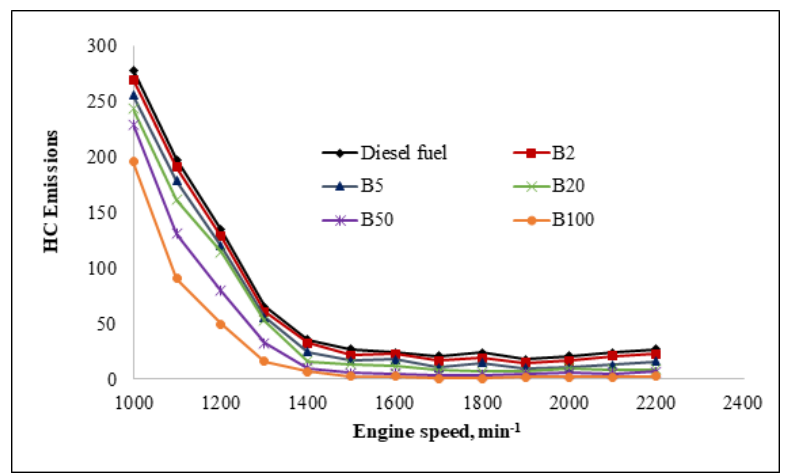

Figure 3.7. Comparison of $\mathrm{HC}$ emission values for diesel, B2, B5, B20, B50 and B100 fuels

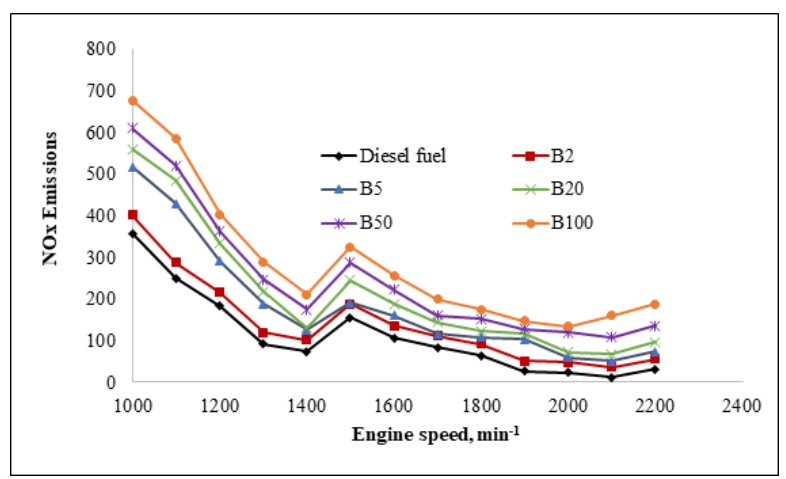

Figure 3.8. Comparison of NOx emission values for diesel, B2, B5, B20, B50 and B100 fuels

\subsection{Comparison of NOx emission values}

The effects of biodiesel on comparison of NOx emission values are presented in Figure 3.8. In general, comparison of NOx emission values increased with the use of biodiesel. Karthikeyan
P. et al. (2017), reported that NOx emissions were lower for all biodiesel mixtures compared to pure diesel. As compared to diesel fuel, such a rise was measured as $26.2 \%$ in B2 fuels, 65.2 $\%$ in B5 fuels, $90.2 \%$ in B20 fuels, $120.9 \%$ in B50 fuels and $156.7 \%$ in B100 fuels.

NOx emissions increased due to raising exhaust gas temperature with using biodiesel. Because, $\mathrm{N}$ and $\mathrm{O}$ atoms react at high temperature. Besides, oxygen content of biodiesel provided more $\mathrm{O}$ atoms for $\mathrm{N}$ atoms [16,29].

\section{Conclusions}

The fuel properties were all within limit values for all fuels. The performance values achieved by using biodiesel and biodiesel blends in diesel engines were quite close to the values obtained from standard diesel fuels. The linseed biodiesel had similar physical characteristics with the standard diesel fuel.

For linseed oil, total fatty acid content was $10.79 \%$, total effective unsaturated fatty acid content was $20.34 \%$ and total polyunsaturated fatty acid content was $68.87 \%$.

Test results revealed that maximum power output was $10.96 \mathrm{~kW}$ with regular diesel fuel, the value was $10.67 \mathrm{~kW}$ with B2, $10.41 \mathrm{~kW}$ with B5, $10.3 \mathrm{~kW}$ with B20, $10.28 \mathrm{~kW}$ with B50 and $10.22 \mathrm{~kW}$ with $\mathrm{B} 100$. While the specific fuel consumption was about $231.36 \mathrm{~g} / \mathrm{kWh}$ for regular diesel fuel, the value was $247.51 \mathrm{~g} / \mathrm{kWh}$ for B2, $268.77 \mathrm{~g} / \mathrm{kWh}$ for B5, $288.28 \mathrm{~g} / \mathrm{kWh}$ for B20, $294.88 \mathrm{~g} / \mathrm{kWh}$ for B50 and $296.73 \mathrm{~g} / \mathrm{kWh}$ for B100.

Exhaust gas temperature, $\mathrm{CO}_{2}$ and $\mathrm{NOx}$ emissions are observed to be higher for linseed biodiesel fuels compared to diesel. Linseed biodiesel mixture fuels have lower $\mathrm{HC}$ and $\mathrm{CO}$ emissions than diesel. As result, this study is show that with linseed biodiesel adding to diesel fuel, exhaust emissions was generally improved.

\section{Acknowledge}

This article is produced from master of science of thesis by Seda Şahin.

\section{References}

1. Işıklı, İ., Yamık, H., Kurban, M., (2011), "Analysis of Biodiesel Usage in Diesel Power Plants", 6th International Advanced Technologies Symposium (IATS'11), 16-18 May 2011, Elazı̆̆ , 20-24. 
2. Anne, M.A., 2010, "Renewable Energy: Sources and Methods", Facts On File, New York, 57-70.

3. Öğüt, H., and Oğuz, H., (2006), "Biodiesel is Third Millennium fuel", Nobel Publication. 2. edition, ISBN 975-591-730-6, Konya.

4. Alptekin, E., Çanakçı, M., (2006), "Biodiesel Production and Determination of Glycerine Properties", Biofuels (BiodieselBioethanol) Symposium, p. 53-60. 29-30 June, TÜBITTAK, Bursa.

5. Karabektaş, M., Ergen, G., (2008), "Heat Balancing in a Diesel Engine Used Biodiesel Fuel". 10th International Combustion Symposium, 424-429.

6. Fukuda, H., Kondo, A., Noda, H., (2001), "Biodiesel Fuel Production by transesterification of Oils". Journal of Bioscience and Bioengineering, 92, ,405-416.

7. Bozdemir, Y., (2007), "Catalase and Superoxide Dismutase Enzymes Activities in Flaxseed (Linum Usitatissimum) Extract", Çukurova University, Graduate School of Science Engineering and Technology, Master thesis.

8. Anonymous, (2013), Turkey, http://www.agaclar.net/forum/tarla-

bitkileri/10459.htm

9. Eckey, E. W., Miller, L. P. Vegetable Fats and Oils. New York: Reinhold Publishing Corporation, p. 530-547 (1954).

10. Hilditchld, T. P., Williams, P. N. The Chemical Constitution of Natural Fats, London: Chapman \& Hail, p. 202-217(1964).

11. Trease, G. E., Evans, W. C. Pharmacognosy, Great Britain:University Press, p. 466- 468 (1972).

12. Akbaş, T., (2000), "Synthesis and Applications of Sunflowerseed and Linseed Oil Based New Macromonomers", Istanbul Technical University, Graduate School of Science Engineering and Tecnology, Master Thesis

13. Karthikeyan, P., Lokesh, P., Suneel, P., (2017), "Performance and emission characteristics of direct injection diesel engine using linseed oil as biodiesel by varying injection timing", International Journal of Ambient Energy, DOI: 10.1080/01430750.2017.1360201.

14. Narsinga, R.L., Shiva, R., Suneel, T.,
2017, "Performance and Emission Characteristics of a Diesel Engine Fuelled W1th Biodiesel by Using Linseed O1l”, International Research Journal of Engineering and Technology (Irjet), Volume: 04 Issue: 04.

15. Tunio, M. M., Luhur, M. R., Ali, Z. M., Daher, U., 2018, "Performance and Emission Analysis of a Diesel Engine Using Linseed Biodiesel Blends", Engineering, Technology \& Applied Science Research Vol. 8, No. 3, 29582962.

16. Ors, I., Kahraman, A., Ciniviz, M., 2017, "Performance, emission, and combustion analysis of a compression ignition engine sing biofuel blends", Thermal Science, 21(1B), 511522.

17. Özener, O., Yüksel, L., Ergenç, A.T., Özkan, M., 2014, "Effects of soybean biodiesel on a DI diesel engine performance, emission and combustion characteristics", Fuel, 115, 875883.

18. Celik, M., Ors, I., Bayindirli, C., Demiralp, M., 2017, "Experimental investigation of impact of addition of bioethanol in different biodiesels, on performance, combustion and emission characteristics", Journal of Mechanical Science and Technology, 31(11), 5581-5592.

19. Mofijur, M., Masjuki, H.H., Kalam, M.A., Atabani, A.E., Arbab, M.I., Cheng, S.F., Gouk, S.W., 2014, "Properties and use of Moringa oleifera biodiesel and diesel fuel blends in a multi-cylinder diesel engine", Energy Conversion and Management, 82, 169176.

20. Ors, I., Kahraman, A., Ciniviz, M., 2017, "Effects on Performance, Emission and Combustion Parameters of Addition Biodiesel and Bioethanol into Diesel Fuel", International Journal of Automotive Engineering and Technologies, 6(4), 148-156.

21. Ong, H.C., Masjuki, H.H., Mahlia, T.M.I., Silitonga, A.S., Chong, W.T., Leong, K.Y., 2014, "Optimization of biodiesel production and engine performance from high free fatty acid Calophyllum inophyllum oil in CI diesel engine", Energy Conversion and Management, 81, 30-40.

22. İlkılıç, C., Aydın, S., Behçet, R., Aydın, H., 2011, "Biodiesel from safflower oil and its application in a diesel engine", Fuel Processing Technology, 92(3), 356-362. 
23. Fattah, I.M.R., Masjuki, H.H., Kalam, M.., Wakil, M.A., Ashraful, A.M., Shahir, S.A., 2014, "Experimental investigation of performance and regulated emissions of a diesel engine with Calophyllum inophyllum biodiesel blends accompanied by oxidation inhibitors", Energy Conversion and Management, 83, 232240.

24. Lesnik, 1., Iljaz, J., Hribernik, A., Kegl, B., 2014, "Numerical and experimental study of combustion, performance and emission characteristics of a heavy-duty DI diesel engine running on diesel, biodiesel and their blends", Energy Conversion and Management, 81, 534546.

25. Randazzo, M.L., Sodre, J.L., 2011, "Exhaust emissions from a diesel powered vehicle fuelled by soybean biodiesel blends (B3-B20) with ethanol as an additive (B20E2B20E5)", Fuel, 90(1), 98-103.

26. Chauhan, B.S., Kumar, N., Cho, H.M., 2012, "A study on the performance and emission of a diesel engine fueled with Jatropha biodiesel oil and its blends", Energy, 37(1), 616622.

27. Rounce, P., Tsolakis, A., York, A.P.E., 2012, "Speciation of particulate matter and hydrocarbon emissions from biodiesel combustion and its reduction by after treatment", Fuel, 96, 90-99.

28. Tan, P., Hu, Z., Lou, D., Li, Z., 2012, "Exhaust emissions from a light-duty diesel engine with Jatropha biodiesel fuel", Energy, 39(1), 356-362.

29. Dhar, A. Kevin, R., Agarwal, A.K., 2012, "Production of biodiesel from high-FFA neem oil and its performance, emission and combustion characterization in a single cylinder DICI engine", Fuel Processing Technology, 97, 118-129. 